\title{
Hydrogeological Framework and Groundwater Balance of a Semi-Arid Aquifer, a Case Study from Iran
}

\author{
Leila Khodapanah ${ }^{1}$, Wan Nor Azmin Sulaiman ${ }^{1}$, Hamid Reza Nassery ${ }^{2}$ \\ ${ }^{1}$ Department of Environmental Sciences, Faculty of Environmental Studies, Universiti Putra Malaysia, \\ Serdang, Malaysia \\ ${ }^{2}$ Faculty of Earth Science, Shahid Beheshti University, Tehran, Iran \\ E-mail: leyla.khodapanah@gmail.com \\ Received January 18, 2011; revised April 17, 2011; accepted May 20, 2011
}

\begin{abstract}
Climate changing and associated factors combined with considerably increases in water demand have been accompanied by severe depletion of reservoir storage of the most groundwater supplies of Iran. Shahriar aquifer in west of Tehran is a representative aquifer of these kinds. In order to meet water demand of the area and protecting groundwater from quantity and quality deterioration, precision recognition of geology, hydrologic and hydrogeologic characteristics of the aquifer is first step. The basic objective of this study is to develop the hydrogeological framework of the groundwater system in Shariar, Iran and to estimate groundwater balance as a scientific database for future water resources delevopment programs. Based on this research lateral groundwater inflows, direct infiltration of rainfall, stream bed infiltration, irrigation return and surplus drinking and industrial water are the recharging factors of the aquifer. Subsurface outflows, domestic and industrial pumping wells and agricultural abstraction are the main parameters discharge the aquifer system. Water balance in the Shahriar aquifer system is in disequilibrium and a deficit of about 24.7 million cubic meters exists.
\end{abstract}

Keywords: Groundwater Balance, Hydrogeology, Alluvial Aquifer, Semi-Arid Basin, Iran

\section{Introduction}

Development of hydrogeological investigation with emphasis on recharge rate estimation is one of the basic steps for a suitable water management [1]. This constitutes a major issue in regions with large demands for ground water supplies, such as in semiarid areas, where such resources are the key to agricultural and industrial development [2-4]. There are various methods for aquifer recharge estimations. Physical and chemical methods are the two main categories for estimating aquifer recharge rate $[5,6]$. Water table fluctuation is one of the most applied methods in recharge estimation. This method calculates the ground water storage change with considering water table fluctuations and the storage parameter. This method is considered to be one of the most promising and attractive due to its accuracy, ease of use and low cost of application in semiarid area [7]. The water table fluctuation method was first used to estimate ground water recharge and has since then has been used in numerous studies for the same purpose [8].
Shahriar plain, situated in west of Tehran and between two rivers Kan and Karaj, was someday considered as one of the main centers of producing sapling and seed in the country. In 1960, Amir Kabir multipurpose dam was constructed on Karaj river for flood storage and regulation, supplying drinking water for Tehran, capital of Iran, agriculture water regulation and supplying hydroelectric power [9]. After several years despite of covering forenamed aims, downstream lands including Shahriar plain was encountered water shortage. Lack of surface water in downstream and feasibility of drilling deep wells has deployed using of Shahriar's groundwater, as these supplies has become main water source of area [10]. Over-exploitation of groundwater resources as a consequent of population growth and rapid development in agriculture and industry has caused water scarcity and drop in groundwater level. Semiarid climate and not recharging aquifer through Karaj River has exacerbated the condition of Shahriar aquifer.

In view of this, there is an urgent need to reevaluate the status of water resources, quantity and quality moni- 
toring of groundwater and better recognition of present aquifer condition for optimum utilizing of water resources in this area. The purpose of this study is to define a conceptual framework of the Shahriar aquifer, to consider the present groundwater resource potential and hydrodynamic characteristics of geological formation of study area. The discharge and recharging parameters of aquifer and water balance of Shahriar groundwater are also assessed.

\section{Materials and Methods}

\subsection{Study Area}

The Shahriar plain covers an area of $580 \mathrm{~km}^{2}$ and lies between longitudes $50^{\circ}$ and $50^{\circ} 15^{\prime}$ east and latitudes $35^{\circ} 30^{\prime}$ and $35^{\circ} 45^{\prime}$ north (Figure 1). The study area is bounded southern submontane of Central Alborz mountains to the north and conglomerate hills to the south, Karaj River to the west and Kan River to the east. The main towns in the area are Shahriar, Saeid Abad, Eslamshahr, Ghale Hasan Khan and Robat Karim. Topographic elevations range from 1020 to $1200 \mathrm{~m}$ above sea level. Mean plain elevation is $1100 \mathrm{~m}$ above sea level. The slope of study area in northeastern and eastern regions is toward south and in northwestern and western is toward southeastern. The general slope is roughly $0.7 \%$.

\subsection{Meteorological and Hydrologic Conditions}

Prevailing climate of study area has semi arid characteristics. According to data of three meteorological stations

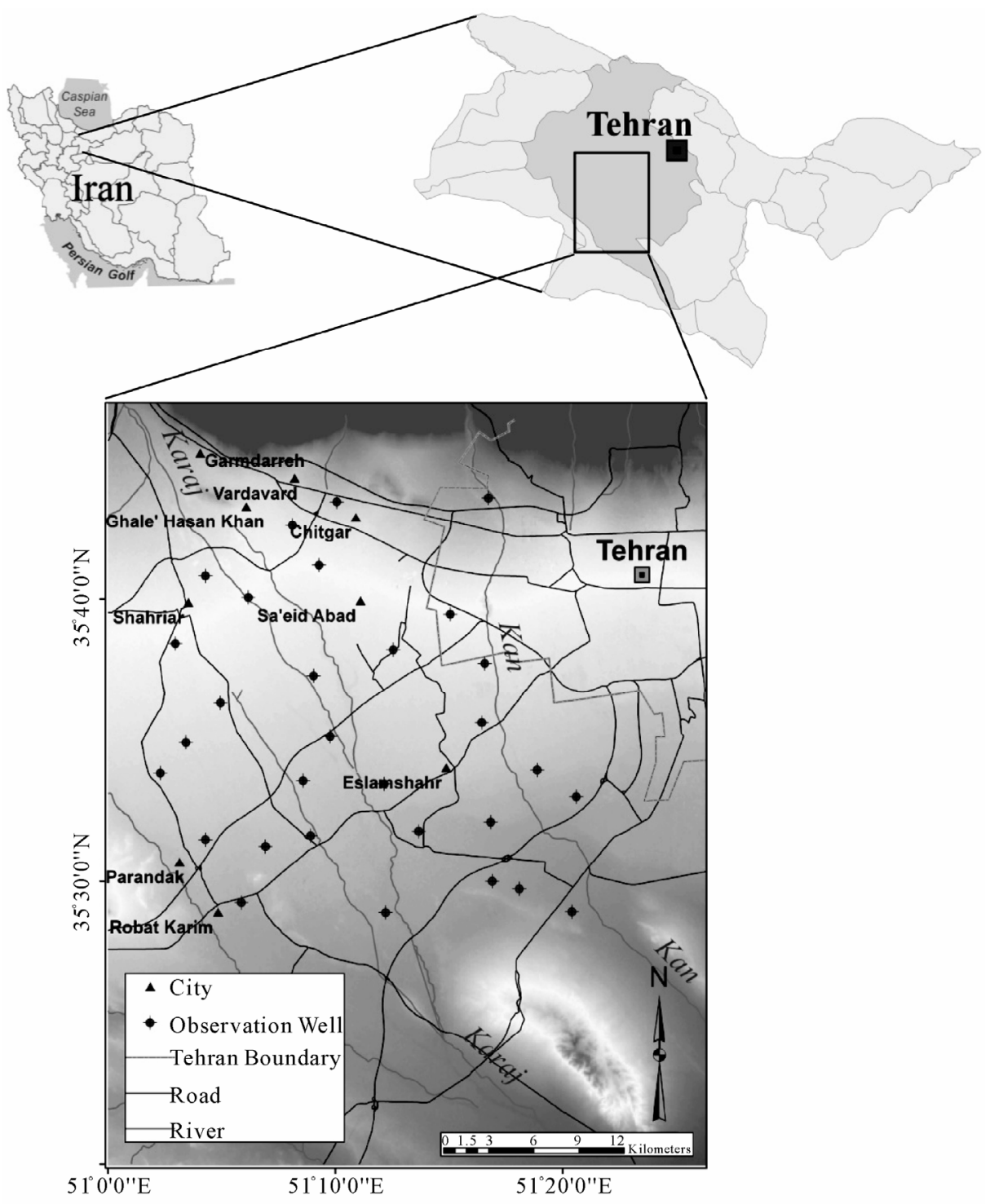

Figure 1. Study area map showing the location of monitoring boreholes. 
existing in the area, average annual precipitation recorded for the years $1967-2005$ is about $230 \mathrm{~mm}$. The wet season begins from November and continues till May. The maximum rainfall occurs in February $(15 \%$ $18 \%$ ) and winter is the most rainy season of the year. The average minimum temperature is $3.5^{\circ} \mathrm{C}$ in January and the average maximum is $30^{\circ} \mathrm{C}$ in August. Mean monthly relative humidity is about $67 \%$ in January and minimum relative humidity is $26 \%$ during the July-September period [11].

The average annual pan evaporation rate measured at Karim Abad station is about $2270 \mathrm{~mm}$. According to Demarton and Emberger climate classification [12], the study area is dry and cold.

There are three rivers in northern mountains which include the Kan, Chitgar and Karaj from east to west. Kan and Karaj are perennial rivers. During wet season Kan joins to Jajrud river in south of Tehran, meanwhile the others become dry in lower part in south of the region due to percolation and evaporation losses as well as diversion of the water for irrigation. All rivers in the region originate from northern catchments and flow toward south and southeast. Three gauging station on main river are Bileghan station on Karaj river and Kahrizak and Sooleghan stations both on the Kan river. The mean discharges of these stations are 15.87, 0.8 and $2.46 \mathrm{~m}^{3}$ per second respectively (Figure 2). The mean discharge of Chitgar river is about $0.5 \mathrm{~m}^{3}$ per second which is calculated based on flow-duration relationships between basins with similar characterisics.

\subsection{Geological Setting}

Shahriar plain is located between Alborz and Central Iran tectonic zones. Present condition and topographic characteristics of study area in south of Central Alborz mountain has been resulted from tectonic processes and the three main river alluvial fans during time, as illustrated in the geological map (Figure 3). The study area is bounded between Alborz mountain and some small conglomerate hills to north and height of different lithology to the south. Central and southern smooth parts of plain form main aquifer and originate from the filling of a tectonic depression with quaternary alluvial. The oldest formation in the area outcrop on the Alborz mountain and southern height and are represented by tuff, andesitic and pyroclastic rocks (Eocene) [13,14]. These rocks which has deposited during the Laramian (laramid) orogenic phase are called Karaj Formation. In the Miocene epoch, there was a marine regression and a change to continental condition, mainly lacustrine, with the deposition of high-colored marls, gypsum, conglomerate and sandstone.

The sediments deposited in this area in the Pliocene epoch caused by Pasadenian orogeny phase are called Hezar Darreh formation. Due to resuming sedimentation till prior quaternary, these sediments are also known as Plio-Quaternar or Late Quaternary Alluvial [15]. Hezar Darreh formation, derived from the uplift of the Alborz Range on the north (Karaj formation tuff), consist of thick coarse light-colored conglomerates and sandstones

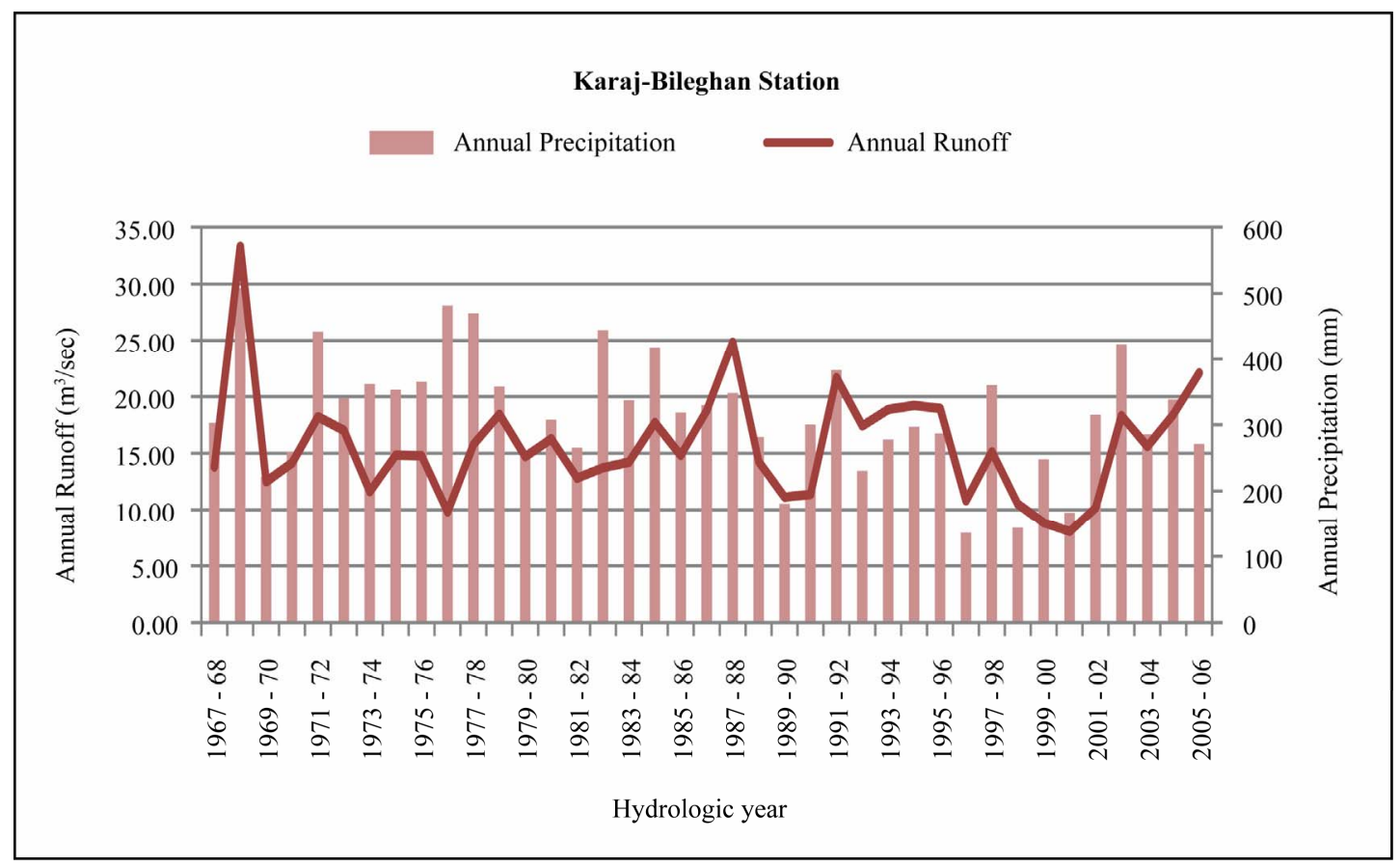

Figure 2. Annual precipitation and runoff in the Karaj-Bileghan station. 


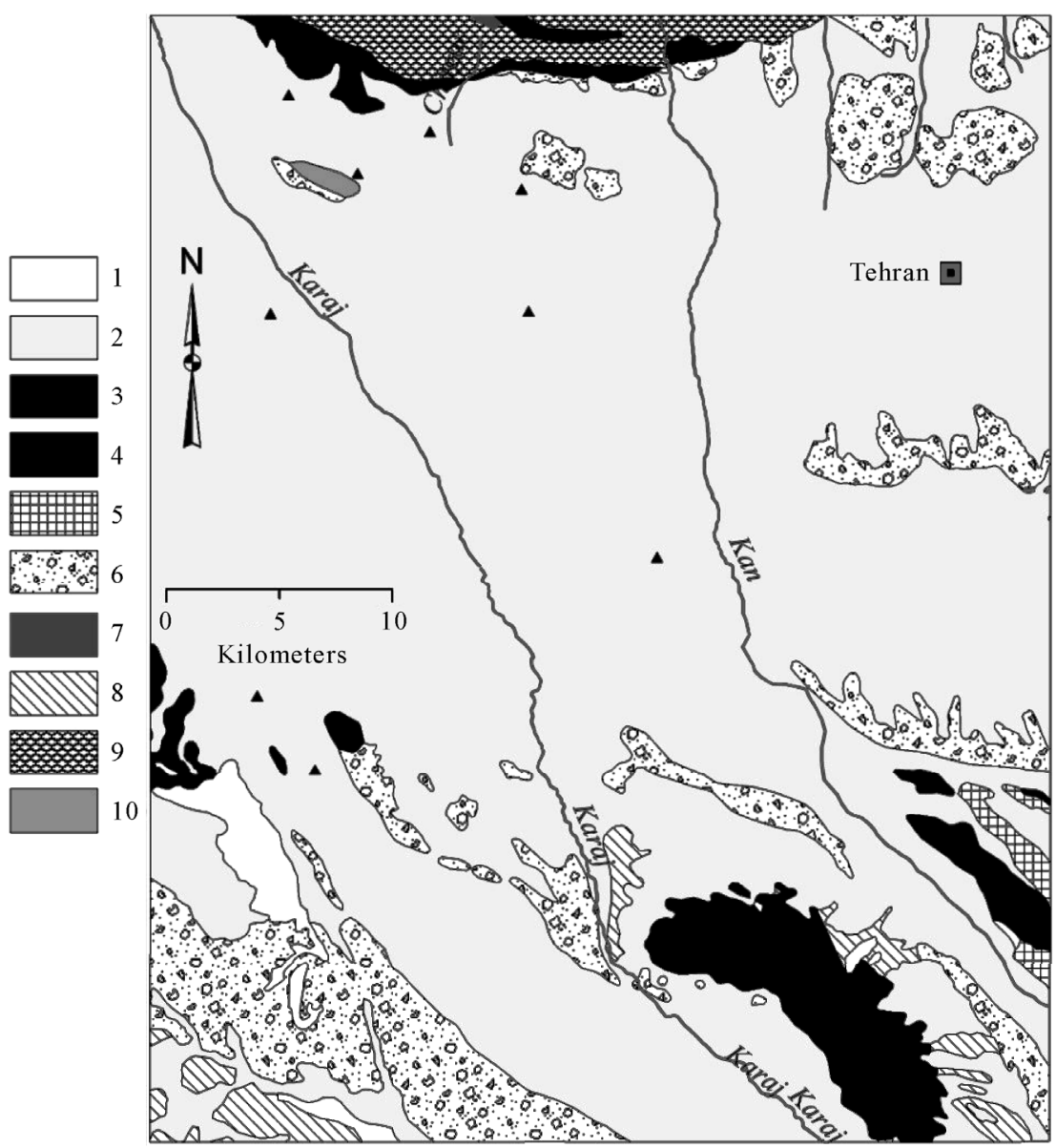

Figure 3. Geological map of the Shariar plain. 1) Alluvial terraces; 2) Alluvium (including TEHRAN ALLUVIUM); 3) Andesite/dacite lava and pyrocalstics marl; 4) Andesitic lava and pyrocalstics; 5) Conglomerate (including HEZARDARREH FORMATION; Mio-Pliocene); 6) Conglomerate (including KAHRIZAK FORMATION; plio-pleistocene); 7) Mudstone, shale, dacite, pyroclastics; 8) Mudstone, gypsiferous; 9) Undifferentiated mudstone, shale, dacite, pyroclastics marl and andesite lava; 10) Upper tuff member: andesite/dacite lava and pyroclastics, shale, marl, sandstone.

more than 1000 - 2000 meters thick near the mountains but increasing to 5000 meters in the eastern Tehran (type profile). This conglomerate alluvium exposed in north of study area (Chitgar and between Vardavard and Garm Darreh) and in southern part as single conglomerate hills.

Most of the Shahriar plain is built on an alluvial fan complex of Recent and Quaternary age that thickens towards the south and thins towards the Alborz Mountains. The Quaternary sediments can be divided to three groups: Kahrizak alluvial formation, Tehran alluvial formation and Recent alluvials [16]. Kahrizak deposits consist of silt and clay and outcrop in south of area near Kahrizak and Mafi Abad. Tehran alluvial, derived from Hezar Darreh erosion, consist of red coarse gravel, sand and silt with good gradation. These deposits host the main aquifer system of the area. Recent Alluvial, the youngest sediments exposed, occur along the Karaj and Kan streams, consists of gravel and sand in northern plain and silt and clay in southern plain.

\subsection{Geoelectrical Measurements and Interpretations}

Vertical electrical soundings with a Schlumberger configuration in the Tehran-Karaj plains have been conducted by [17]. 144 soundings in 11 profiles were conducted in Shahriar plain. The apparent resistivity data obtained for different values of $\mathrm{AB} / 2$ have been processed. These results were subsequently used to obtain a realistic picture of the geological and hydrogeological framework.

Based on different particle size in unconsolidated horizons, electrical resistivity varies from $10-250 \Omega \mathrm{m}$. Lower resistivities occur in central and southern parts of study area, where as clay and silt zones are predominant. Data derived from lithology of boreholes and drilled wells located in the vicinity of corresponding soundings were compared with geoelectrical surveys results to obtain the true resistivity values, the thickness and the li- 
mitations of the alluvial aquifer. The resultant isopach map (Figure 5(a)) shows that aquifer thickness varies from a few meters to about $250 \mathrm{~m}$. It increases from 25 $100 \mathrm{~m}$ in northern edge of the plain to $100-250 \mathrm{~m}$ in the central parts of plain. Aquifer thickness decreases toward south of area where it reaches to its minimum.

\subsection{Hydrogeologial Setting}

The rapid increase in the population, caused by migration of people from adjacent provinces to the Tehran province, has led to large-scale groundwater developments in the study area over past two decades. As a result, aquifer condition has been changed egregiously during these years.

Based on time-drawdown and recovery data from 8 observation wells, transmissivity is about $750 \mathrm{~m}^{2} \cdot \mathrm{d}^{-1}$ in northern parts and up to $3000 \mathrm{~m}^{2} \cdot \mathrm{d}^{-1}$ in central parts of the plain (Figure 5(b)). It decreases again toward south where it is about $500 \mathrm{~m}^{2} \cdot \mathrm{d}^{-1}$ in outlet of basin. Storage coefficient ranges between $0.25-0.35$.

Drilled wells logs, water level in observing wells and geophysical investigations shows that main aquifer of Shahriar plain is an unconfined aquifer whose alluvial particle size varies from gravel and sand in north to silt and clay in south. The groundwater occurrence changes according to topographical and subsurface geological conditions. For example the water level is over $100 \mathrm{~m}$ below groundwater in the northernmost parts of the area and gradually gets closer to the ground surface toward the south of outlet of plain where it is about $10 \mathrm{~m}$ below ground level (Figure 5(c)).

Water levels of 30 observing wells have been used to draw isopotential maps of groundwater level in Shahriar plain. Based on this map, ground water flows from the northern heights and recharge areas of Karaj and Kan rivers toward the central parts and finally discharges to the outlet of the plain. The hydraulic gradient in the study area has its maximum value $(13.5 \%-18 \%)$ in north. While in central zone, due to increasing of saturated thickness of aquifer, its minimum values are found. Towards the study area's southern border and outlet of plain, hydraulic gradient increases again $(3 \%-8 \%)$.

Long-term and seasonal average areal water-level fluctuations recorded in 30 observing wells are plotted during the period 1989-2002. The mean values are calculated by creating Thiessen polygons for observation well stations. According to hydrograph analysis of observing wells it is concluded that there is an average decline of about $13.2 \mathrm{~m}$ in the groundwater level. Figure 4 shows the water level fluctuation of the Shahriar plain.

According to Tehran Regional Water Authority [18], pumping wells are the main and only way to groundwater exploitation. All qanats and springs existing in the area have been dried in recent years due to intensive water level decline. The total withdrawal from deep and shallow pumping wells are 223, 57 and 38 million $\mathrm{m}^{3 /}$ year for agriculture, drinking and industrial pumping wells respectively.

\subsection{Groundwater Balance}

In this study, a groundwater balance has been prepared for the Shahriar aquifer based on available inflows, outflows and changes in the aquifer groundwater storage. The study was conducted for the period 1999 - 2000. In a specified period changes in volume storage of an aquifer depends on average flows entering and leaving the system through the different sources and sinks. Therefore the groundwater balance has two components: the total

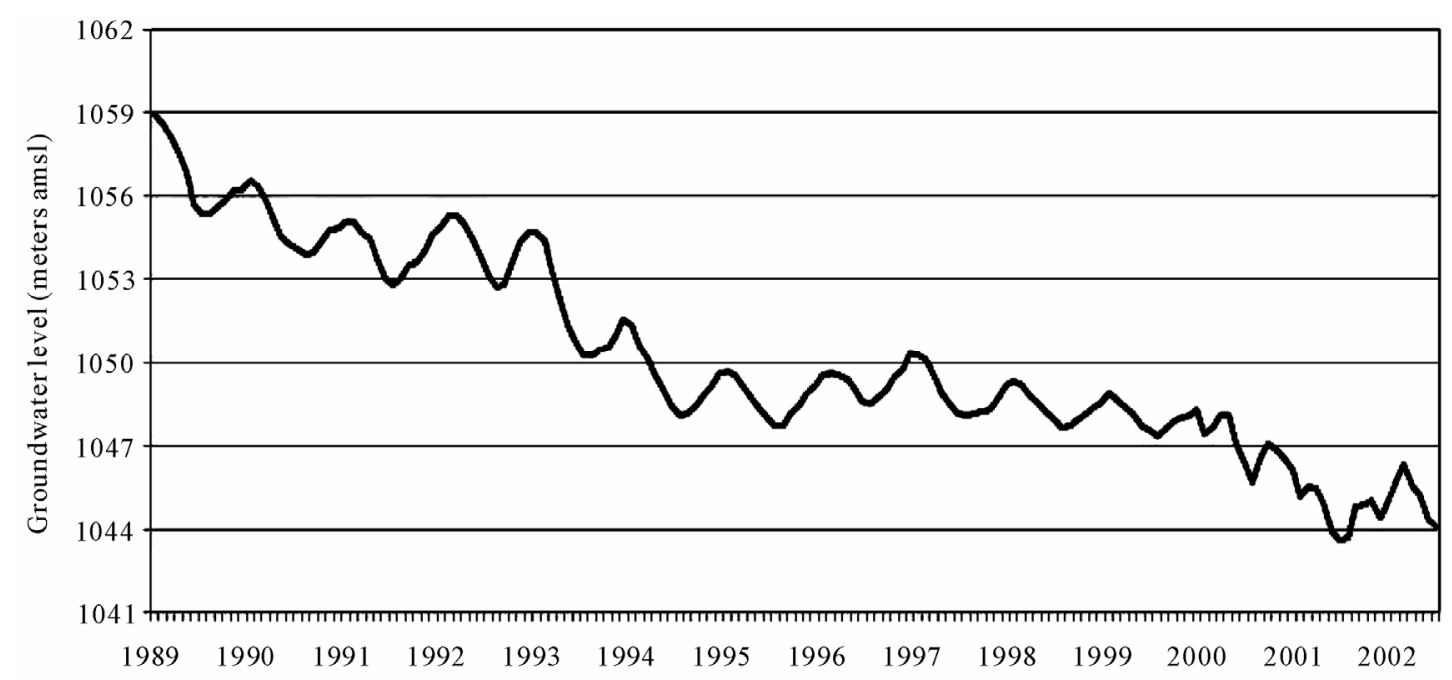

Figure 4. Groundwater level fuctuation of the Shahriar aquifer (Data derived from 30 monitoring boreholes). 


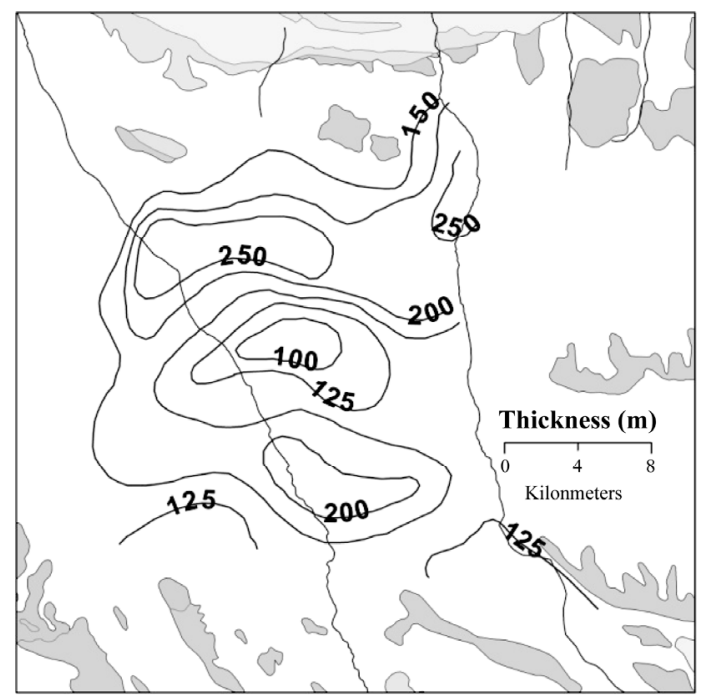

(a)

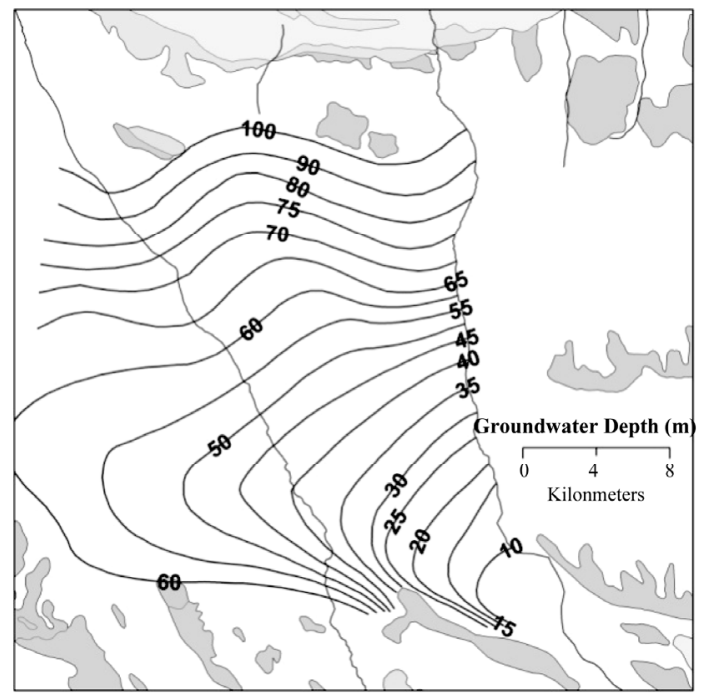

(c)

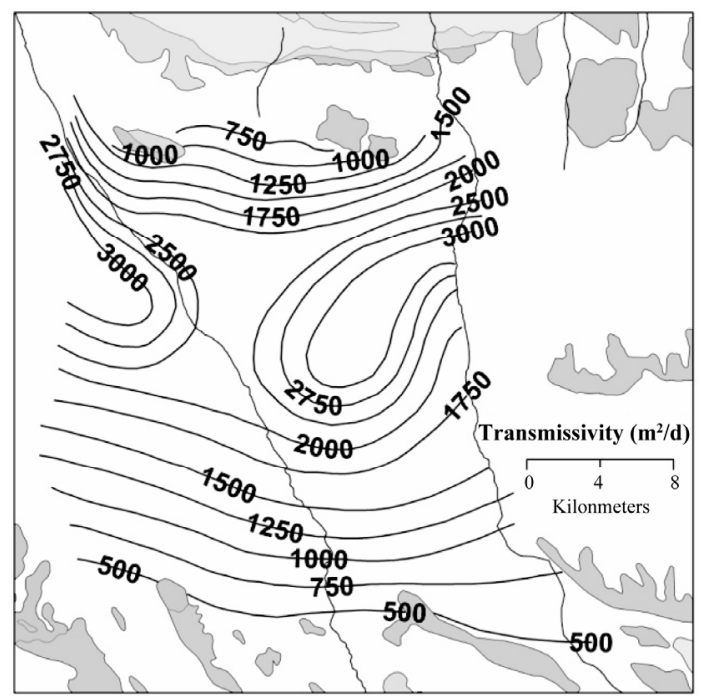

(b)

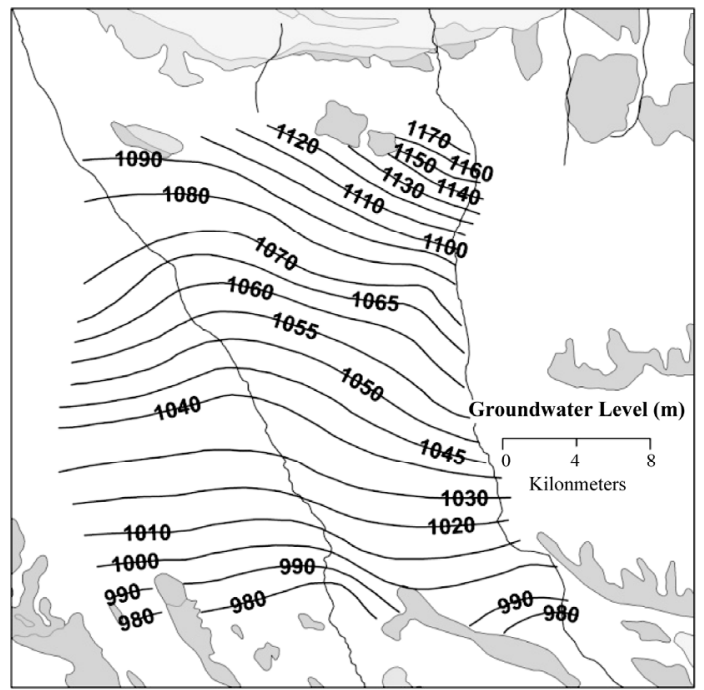

(d)

Figure 5. Hydrogeological maps of the study area: (a) Thichness isopack map; (b) Transmissivity; (c) Groundwater table depth; (d) Groundwater level.

input $\left(\Sigma Q_{\text {in }}\right)$ and the total output $\left(\Sigma Q_{\text {out }}\right)$. The equation for the groundwater balance during a specified hydrological period can be written as [19]

$$
\Sigma Q_{\text {in }}-\Sigma Q_{\text {out }}= \pm \Delta V
$$

where $\Delta V$ is the change in groundwater storage.

In Shahriar plain the total groundwater input $\left(\Sigma Q_{\text {in }}\right)$ consists of: lateral subsurface inflows $\left(Q_{1}\right)$, rainfall recharge $\left(Q_{2}\right)$, Mountain-front recharge $\left(Q_{3}\right)$, recharge due to irrigation returns $\left(Q_{4}\right)$, recharge due to domestic and industrial wells returns $\left(Q_{5}\right)$ and streambeds and canal infiltrations $\left(Q_{6}\right)$

$$
\Sigma Q_{\text {in }}=Q_{1}+Q_{2}+Q_{3}+Q_{4}+Q_{5}+Q_{6}
$$

The total groundwater output $\left(\Sigma Q_{\text {out }}\right)$ consists of subsurface outflows $\left(Q_{7}\right)$ and pumping groundwater $\left(Q_{8}\right)$

$$
\Sigma Q_{\text {out }}=Q_{7}+Q_{8}
$$

The change in groundwater storage $(\Delta V)$ can be estimated as

$$
\Delta V=A \cdot S_{c} \cdot \Delta h
$$

where:

$A=$ Area of aquifer

$\Delta h=$ Difference between the average water level at during the hydrological period and

$S_{c}=$ Average storativity of aquifer 


\section{Results and Discussion}

Groundwater recharge and discharge in the Shahriar aquifer occurs via seven and two components respectively. These components are contributing in groundwater system as explained below:

\subsection{Lateral Subsurface Inflows $\left(Q_{1}\right)$}

Inflow and outflow cross sections were determined using equipotential groundwater level map (Figure 5(d)) for October 1999 (23 cross sections). Employing Darcy's law and transmissivity map, an estimate of the volume of lateral inflows from the upstream boundary of the aquifer was performed:

Inflow amount $\left(Q_{1}\right)=$ average transmissivity $(T) \times$ cross sectional length $(L) \times$ gradient $(i) \times$ water balance period $(t)$.

For each cross section volume of inflow was calculated using mentioned equation. The total lateral inflows to the aquifer system were calculated to be $Q_{1}=167$ Million $\mathrm{m}^{3} \cdot \mathrm{yr}^{-1}$ for the hydrological year 1999-2000.

\subsection{Rainfall Recharge $\left(Q_{2}\right)$}

Various parameters such as annual rainfall depth, slope and soil permeability affect the rainfall recharge amount. Accepting annual rainfall depth about $225 \mathrm{~mm}$ for year $1999-2000$ and the area about $580 \mathrm{~km}^{2}$ the annual rainfall volume equals 130 million $\mathrm{m}^{3}$.

The infiltration ratio considering the lithology and soil texture is estimated $10 \%$ of the annual rainfall. Thus in this study the annual recharge of the aquifer system from rainfall was estimated to be $Q_{2}=13$ million $\mathrm{m}^{3} \cdot \mathrm{yr}^{-1}$.

\subsection{Mountain-Front Recharge $\left(Q_{3}\right)$}

As mentioned in hydrology section, the annual volume of entering runoff to study area via three sub-basins named Kan-Chitgar, Chitgar, and Chitgar-Karaj are about 1.5, 13.5 and 3 respectively and totally about 18 million $\mathrm{m}^{3}$. The total recharge through these runoffs is estimated about 15 million $\mathrm{m}^{3}$.

\subsection{Recharge Due to Irrigation Returns $\left(Q_{4}\right)$}

According to FAO technical paper about irrigation yield and percolate water losses in farms based on irrigation method and soil texture [20], the irrigation returns are estimated to be as high as $25 \%$ of the applied irrigation (223 million $\mathrm{m}^{3} \cdot \mathrm{yr}^{-1}$ from agricultural wells, 29 million $\mathrm{m}^{3} \cdot \mathrm{yr}^{-1}$ through water pumping from streams and canals). Hence, recharge from irrigation returns is 63 million $\mathrm{m}^{3} \cdot \mathrm{yr}^{-1}$.

\subsection{Recharge Due to Domestic and Industrial Wells Returns $\left(Q_{5}\right)$}

Conciderably percent of water applying for drinking and household uses, turns to wastewater and to some extent percolate to the aquifer. Groundwater extracted for municipal uses from the region aquifer is about 57 million $\mathrm{m}^{3} \cdot \mathrm{yr}^{-1}$. The amount of return flow from these well is estimated about 37 million $\mathrm{m}^{3} \cdot \mathrm{yr}^{-1}(65 \%$ of the total amount).

The total amount of groundwater abstracted for industrial uses is about 38 million $\mathrm{m}^{3} \cdot \mathrm{yr}^{-1}$ which is estimated $35 \%$ of this amount ( 13 million $\mathrm{m}^{3} \cdot \mathrm{yr}^{-1}$ ) percolate to the aquifer. Therefore the recharge due to domestic and industrial wells calculated as $Q_{5}=37+13=50$ million $\mathrm{m}^{3} \cdot \mathrm{yr}^{-1}$.

\subsection{Streambed and Canals Infiltrations $\left(Q_{6}\right)$}

The total volume of inflow to study area through Navvab canal is 24 million $\mathrm{m}^{3} \cdot \mathrm{yr}^{-1}$. From this amount 5 million $\mathrm{m}^{3} \cdot \mathrm{yr}^{-1}$ is being used for irrigation that 1.3 million $\mathrm{m}^{3} \cdot \mathrm{yr}^{-1}(25 \%)$ participates in aquifer recharging. From the rest of total volume (19 million $\left.\mathrm{m}^{3} \cdot \mathrm{yr}^{-1}\right), 1.9$ million $\mathrm{m}^{3} \cdot \mathrm{yr}^{-1}$ (tantamount $10 \%$ ) infiltrates to aquifer system.

Eight Streams are taking supply from Bileghan diversion dam in north west of study area. The recharge to the aquifer system from streambed infiltration was estimated to be 2.1 million $\mathrm{m}^{3} \cdot \mathrm{yr}^{-1}$ ( $10 \%$ of total streams flow). From the estimates made above, the annual input to the Shahriar alluvial aquifer is $\Sigma Q_{\text {in }}=Q_{1}+Q_{2}+Q_{3}+Q_{4}+$ $Q_{5}+Q_{6}=328.3$ million $\mathrm{m}^{3} \cdot \mathrm{yr}^{-1}$

The output parameters of the aquifer are groundwater extraction and groundwater discharge across sub-basin boundaries. According to water table depth map of study area which shows minimum depth of water table is more than 5 meter in the region, Evaporation from groundwater has been considered negligible.

\subsection{Lateral Subsurface Outflows $\left(Q_{7}\right)$}

The total lateral subsurface outflows to the aquifer system were calculated to be $Q_{7}=20$ million $\mathrm{m}^{3} \cdot \mathrm{yr}^{-1}$ according to Darcy's law as it mentioned in lateral inflows.

\subsection{Pumping Groundwater $\left(Q_{8}\right)$}

Groundwater exploitations are performed via numerous production wells in order to cover the regional needs as below.

Based on the data of pumping wells from the Tehran 
Table 1. Groundwater balance.

\begin{tabular}{cccc}
\hline Water input (million $\left.\mathrm{m}^{3} \cdot \mathrm{yr}^{-1}\right)$ & & Water output $\left(\mathrm{million}^{3} \cdot \mathrm{yr}^{-1}\right)$ \\
\hline Lateral groundwater fluxes & 167 & Subsurface outflows & 20 \\
Recharge due to rainfall & 13 & Agricultural abstractions & Domestic use \\
Mountain-front recharge & 15 & Industrial use & 37 \\
Irrigation return & 63 & & \\
Domestic and industrial wells returns & 50 & & 338 \\
Streambed and canal infiltration & 5.3 & & \\
\hline
\end{tabular}

Regional Water Board inventory report, groundwater abstracted from the Shahriar aquifer is 223,57 and 38 million $\mathrm{m}^{3} \cdot \mathrm{yr}^{-1}$ for agricultural, Domestic and industrial consumptions respectively.

From the estimates made above, the mean annual output from the Shahriar alluvial aquifer is $\Sigma Q_{\text {out }}=Q_{7}+Q_{8}$ $=20+318=338$ million $\mathrm{m}^{3} \cdot \mathrm{yr}^{-1}$

As illustrated in Table 1, a negative groundwater balance has been calculated in the studied aquifer system for the year 1999-2000. Groundwater overexploitation by abstractions from over 3500 production wells has resulted in considerable head decline that reached $1.42 \mathrm{~m}$ during the hydrological year 1999-2000. It can be concluded that the current abstraction is not sustainable, thus groundwater is withdrawn from storage. The impacts of the overexploitation are the drying up of upper aquifer system wells and qanats, the land subsidence $[21,22]$ and the severe deterioration of groundwater quality.

There are some strategies in order to make the Shahriar groundwater system sustainable. Groundwater exploitation controlling based on plant water demand and restriction the irregular pumping wells' drilling can play an important role in decreasing the depletion of water table. Utilization of the treated wastewater and the application of water-saving techniques such as spray irrigation and drip irrigation can decrease the groundwater quantities for irrigation use [23,24].

Artificial recharge is another alternative as a valuable water management tools that effectively help to offset increased demands for water [25]. Availability, quality and quantity of source water available, resulting water quality (reactions with native water and aquifer materials), clogging potential, underground storage space available, depth to underground storage space, transmission characteristics, and costs are some factors controlling the feasibility of artificial recharge method [26]. The lithological studies in the study area reveals that the northern parts especially in Chitgar and the region between Saeid Abad, Ghale Hasan Khan and Shariar can be considered as suitable recharging zones due to thick and permeable horizons of coarse grain deposits.

Therefore, an appropriate set of management strategies, including water conservation measures, regulation of existing development, improvement of current legislation and public education should be adopted [3]. Future investigations of the groundwater recharge in the alluvial aquifer system would benefit by improvement in hydrological data monitoring, the application of isotopic analysis and computer modeling to simulate the water cycle and groundwater flow.

\section{Acknowledgements}

The authors wish to thank Tehran Regional Water Authority for supplying the existing relevant data. Also, the constructive comments of anonymous reviewers will be appreciated.

\section{References}

[1] E. Wendland, C. Barreto and L. H. Gomes, "Water Balance in the Guarani Aquifer Outcrop Zone Based on Hydrogeologic Monitoring," Journal of Hydrology, Vol. 342 , No. 3-4, 2007, pp. 261-269. doi:10.1016/i.jhydrol.2007.05.033

[2] J. C. Marechal, B. Dewandel, S. Ahmed, L. Galeazzi and F. K. Zaidi, "Combined Estimation of Specific Yield and Natural Recharge in a Semi-Arid Groundwater Basin with Irrigated Agriculture," Journal of Hydrology, Vol. 329, No. 1-2, 2006, pp. 281-293. doi:10.1016/j.jhydrol.2006.02.022

[3] A. T. Tizro, K. S. Voudouris and M. Eini, "Groundwater Balance, Safe Yield and Recharge Feasibility in a Semi-Arid Environment: A Case Study from Western Part of Iran," Journal of Applied Sciences, Vol. 7, No. 20, 2005, pp. 2967-2976.

[4] G. R. Lashkaripour, "Contamination of Groundwater Resource in Zahedan City Due to Rapid Development," Journal of Applied Science, Vol. 3, No. 5, 2003, pp. 341-345. doi:10.3923/jas.2003.341.345

[5] G. B. Allison, "A Review of Some of the Physical Chemical and Isotopic Techniques Available for Estimat- 
ing Ground Water Recharge," In: I. Simmers, Ed., Estimation of Natural Ground Water Recharge, Reidel, Dordrecht, 1988, pp. 49-72.

[6] S. S. D. Foster, "Quantification of Ground Water Recharge in Arid Regions: A Practical View for Resource Development and Management," In: I. Simmers, Ed., Estimation of Natural Ground Water Recharge, Reidel, Dordrecht, 1988, pp. 323-338.

[7] R. W. Healy and P. G. Cook, "Using Groundwater Levels to Estimate Recharge," Hydrogeology Journal, Vol. 10, No. 1, 2002, pp. 91-109. doi:10.1007/s10040-001-0178-0

[8] C. Leduc, J. Bromley and P. Schroeter, "Water Table Fluctuation and Recharge in Semi-Arid Climate: Some Results of the HAPEX-Sahel Hydrodynamic Survey (Niger)," Journal of Hydrology, Vol. 188-189, 1997, pp. 123-138. doi:10.1016/S0022-1694(96)03156-3

[9] Tehran Regional Water Authority Website, 2009. http://www.tw.org.ir/dams/selectdam_en.asp

[10] Tehran Regional Water Authority, "Annual Report of Groundwater Resources Exploitation," Deputy for Water Resources Study and Research, Tehran Regional Water Authority, 2005.

[11] Water Resources Studies Division, "Climatology and Hydrologic Report of Tehran, Varamin and Shahriar Basins," Tehran Regional Water Authority, 1997.

[12] A. Alizadeh, "The Principle of Applied Hydrology," Astan Ghods Razavi Publications, Mashhad, 2009.

[13] A. Darvishzadeh, "Geology of Iran," Amirkabir Publication, Tehran, 2003.

[14] S. A. Aghanabati, "Geology of Iran," Geological Survey of Iran Publication, Tehran, 2004.

[15] C. Vita-Finzi, "Late Quaternary Alluvial Chronology of Iran," Geologische Rundschau, Vol. 58, No.2, 1969, pp. 951-973. doi:10.1007/BF01820740

[16] E. H. Rieben, "The Geology of the Tehran Plain," American Journal of Science, Vol. 253, 1955, pp. 617-639. doi:10.2475/ajs.253.11.617

[17] Water and Soil Engineering Unit of Jihad-e-Sazandegi,
"Geoelectrical Studies in Tehran-Karaj Plain," Jihad-eSazandegi Ministry, Tehran, 1983.

[18] Tehran Regional Water Authority, "Detailed Data Collection from Discharges of Pumping Wells and Qanats in Tehran Province," Tehran Regional Water Authority, Tehran, 2001.

[19] J. J. Carrillo-Rivera, "Application of the Groundwater-Balance Equation to Indicate Interbasin and Vertical Flow in Two Semi-Arid Drainage Basins, Mexico," Hydrogeology Journal, Vol. 8, No. 5, 2000, pp. 503-520. doi: $10.1007 / \mathrm{s} 100400000093$

[20] A. Alizadeh, "Relation between Water, Soil and Plant," Astan Ghods Razavi Publications, Mashhad, 2007.

[21] A. Shemshaki and I. E. Soltani, "Land Subsidence Review at Sahariar Plain," Geological Survay of Iran, Tehran, 2004.

[22] R. Umar, M. M. A. Khan, I. Ahmed and Sh. Ahmed, "Implications of Kali-Hindon Inter-Stream Aquifer Water Balance for Groundwater Management in Western Uttar Pradesh," Journal of Earth System Science, Vol. 117, No. 1, 2008, pp. 69-78. doi:10.1007/s12040-008-0014-1

[23] P. K. Naik, and A. K. Awasthi, "Groundwater Resources Assessment of the Koyna River Basin, India," Hydrogeology Journal, Vol. 11, No. 5, 2003, pp. 582-594. doi:10.1007/s10040-003-0273-5

[24] M. N. Bhutta, M. Saeed and M. Rafiq, "Evaluation of Groundwater Balance-A Case Study of Mona Drainage Basin," Pakistan Journal of Water Resources, Vol. 11, No. 2, 2007, pp. 19-26.

[25] K. Voudouris, P. Diamantopoulou, G. Giannatos and P. Zannis, "Groundwater Recharge via Deep Boreholes in the Patras Industrial Area Aquifer System (NW Peloponnesus, Greece)," Bulletin of Engineering Geology and the Environment, Vol. 65, No. 3, 2006, pp. 297-308. doi:10.1007/s10064-005-0036-8

[26] M. P. O’Hare, D. M. Fairchild, P. A. Hajali and L. W. Canter, "Artificial Recharge of Groundwater: Status and Potential in the Contiguous United States," Lewis Publishers, Chelsea, 1986. 